Changing Family Realities in South Asia?

\title{
Negotiating Middle-class Respectable Femininity: Bangladeshi Women and their Families
}

\section{Nazia Hussein}

\section{(2) OpenEdition}

1 Journals

Electronic version

URL: https://journals.openedition.org/samaj/4397

DOI: $10.4000 /$ samaj.4397

ISSN: $1960-6060$

Publisher

Association pour la recherche sur l'Asie du Sud (ARAS)

\section{Electronic reference}

Nazia Hussein, "Negotiating Middle-class Respectable Femininity: Bangladeshi Women and their Families", South Asia Multidisciplinary Academic Journal [Online], 16 | 2017, Online since 11 September 2017, connection on 21 September 2021. URL: http://journals.openedition.org/samaj/4397 ; DOI: https://doi.org/10.4000/samaj.4397

This text was automatically generated on 21 September 2021.

\section{(i) (9)}

This work is licensed under a Creative Commons Attribution-NonCommercial-NoDerivatives 4.0 International License. 


\title{
Negotiating Middle-class Respectable Femininity: Bangladeshi Women and their Families
}

\author{
Nazia Hussein
}

\section{Introduction}

1 The growth of neo-liberalization, an urban wage economy, and internal and international migration have fundamentally changed household structure and family ideology in Bangladesh. Since the 1990s, urban middle-class Bangladeshi women's participation in the public domain as active economic agents has shifted the power relations in couples and families, particularly because professional women now seek familial support systems to find a substitute for their domestic work. Yet studies of Bangladeshi families predominantly address women's oppression within families in relation to patriarchy (Chowdhury 2009), domestic violence (Schuler, Hashemi and Akhter 1996; Koenig et al. 2003; Bates et al.2004; Heath 2014) and women's reproductive role (Schuler, Hashemi and Riley 1997). But the nitty-gritty of family life such as changing household settings, intra-household and intergenerational relations, practices surrounding gender roles such as motherhood, daughters-in-law, and women's contribution to family construction and the maintenance of middle-class status are overlooked.

2 This bias against studies of family structures and everyday practices of gender and class within families also prevails in literature on globalization, economic liberalization, Islam's revival and sexuality studies in South Asia and Bangladesh. While much research in India and emerging literature in other South Asian countries like Sri Lanka, Nepal and Bangladesh address the transformation of women's roles in urban areas, it is largely focused on women's involvement in the "public" sphere through employment and education (Radhakrishnan 2009, 2011; Liechty 2003; Kabeer 1997, 2000). Additionally, the 
growing visibility of Islamic practices such as the headscarf and burqa ${ }^{1}$ among women has been addressed in recent research on women's agency and respectability (Hussain 2010), empowerment (White 2010; Rozario 2006) and honor (Naher 2010). Finally, a nascent body of literature addresses sexualities, non-heterosexual relationships and post-liberalization lifestyles since the 2000s (Osella and Osella 2004; Karim 2010). Yet the growth of Bangladesh's new and affluent urban middle class, their contribution to social transformation, and their numbers, characteristics, diversity and gender dynamics are under-researched (Lewis 2011). Shahidullah (1985) recognized that the economic reforms of the late 1970s and 1980s influenced the growth of the new middle class. Van Schendel (2009) saw the complexities of this middle stratum through their role in the reproduction of a Bengali cultural pride, their involvement in politics and economics, and their investment in education. Janeja (2010) identified the role of food and café culture and Mapril (2013) studied international labor migration as constitutive of the new middleclass in Bangladesh. In this paper, I explore the changing structure of urban middle-class Bangladeshi women's household patterns, which have an impact on their negotiations with respectable femininity within the family and on the construction of a new affluent middle-class.

Normative conceptions of respectable femininity in Bangladesh, and South Asia at large, involve women prioritizing family above work through domesticity, caring and socializing roles and moral propriety. Using sociology of class (Bourdieu 1992, 2008) and boundary work (Lamont 1992), I present normative boundaries of middle-class respectability as a binding force or a "burden" that women navigate through their contribution to class privilege. As middle-class women gain access to higher education, highly-paid employment, capital investments of goods, high-fee English-medium education, concerted cultivation of children, and foreign tourism, they can change their gendered roles within the family and society. I argue that the achievements of these women give them a significant say in their own life trajectories, even though they do not eliminate conventional expectations of middle-class respectable femininity. Focusing on women's familial negotiations, I demonstrate how the research participants add value and legitimacy to their self-aspirations. A gendered power lies in women's ability to legitimize which status claims are respectable in what context. I argue that a professional career and capital investment add respectability, making it acceptable for a woman to be allowed autonomy and live life on her own terms in Bangladesh. Such new constructions of women's respectability enable us to deconstruct the binaries of tradition and modernity or respectable and unrespectable, and carve out a third or "other" site (Menon 2005) for women to bring some improvement to their inferior gender position in a patriarchal society.

\section{Boundaries of respectable femininity}

Following Skeggs (1997), I use Bourdieu's $(1992,2008)$ model of class based on "capital" movements in social space, and conceptualize respectable femininity as a symbolic capital that illuminates the embeddedness of gender and class. Capital is a set of common properties, objectified or sometimes legally guaranteed, such as possession of one or more goods, or a set of embodied practices such as clothing (Bourdieu 1992:101, 2008:280). Bourdieu's multidimensional approach to class is based on economic (income, wealth), cultural (education, embodied aesthetics), social (friends, colleagues) and symbolic 
(prestige, honor) capital movements, which can confer strength, power and profit to their holder (Bourdieu 1992). Respectable femininity is a symbolic capital that women seek in order to gain symbolic profit and class status. Symbolic capital is the form that any other kind of capital (economic, cultural and social) can take once it is perceived as legitimate. Legitimization occurs when one's privileged taste and capitals are considered part of one's "natural" capacity, misrecognizing all others as inferior and reproducing the dominance of the privileged (Laberge 1995). Bourdieu maintains that all distinctive/ classed lifestyles are defined by the mutual relationship of habitus, capital and the field. The distinctive "taste" of the class is derived from its agents' "homogeneous conditions of existence (field), production of homogeneous systems of dispositions capable of generating similar properties ... and practices (capital) ... within a set of common properties embodied as class habitus" (Bourdieu 1992:101).

5 Respectable femininity is based around particular types of femininity, aesthetics, caring and morals, always seeking to get something "right"; it is articulated as a process through which women add value to themselves (Skeggs 1997). It manifests as behavioral expectations in workplaces, streets and homes. Respectability has long been a discourse used to differentiate middle and working classes (Skeggs 2004). For Watt (2008), respectability offers new insights into the experiences of living in both inner and suburban London. The use of respectable femininity to define middle-class status highlights feminist concerns around invisibility of gender in the Bourdieusian construction of class (Lovell 2000; Skeggs 2004). Additionally, McDowell (2008) argues that, given women's ever-increasing participation in the labor force, the division of labor along gender lines within the household must be reconsidered to investigate how it contributes to new class politics in the UK and USA. In this paper, I agree with these feminist accounts of class and evaluate how the constant struggle to gain value and legitimacy-thus status and power ${ }^{2}-$ through respectability enables participants in this research to distance themselves from other women.

In Victorian Britain women's respectability was related to domesticity, appropriate language, behavior (Skeggs 1997) and sexual restraint (Frances 1994). Practices of respectable femininity are traceable in colonial India, especially Bengal, through the educational attainments of the middle-class bhodromohila, ${ }^{3}$ the respectable woman, who was expected to acquire education and cultural refinement to make her a worthy companion to her husband, without jeopardizing her feminine spiritual (domestic) virtues or her place in the home (Chatterjee 1989:628). Three themes dominated the literature on urban Hindu and Muslim Bengali bhodromohila's status as superior to other women: the ideal of pativrata (a wife worshipping her husband), a woman's subordinate position to a man as part of her Dharma (duty), and the separation of public and private spheres. Even educated women would not participate in the public sphere, reflecting older notions of purdah (seclusion) (Donner 2008:44). In postcolonial East Pakistan, middle-class women's cultural practices were central to Bangladesh's independence movement, which sought to establish a secular fusion identity, including aspects of their religion, Islam, and Bengali cultural practices, such as the sari and wearing a bindi ${ }^{4}$ on their forehead. This identity constituted Bengali middle-class women's respectability. In contemporary Bangladesh, religious clothing such as headscarves and burqas have been associated with lower middle-class women's respectability (White 2010; Hussain 2010). Elsewhere in South Asia, respectable femininity and its association with the family plays 
out in the individual choices of professional women and their prioritizing family above work (Radhakrishnan 2009:201).

7 Normative conceptions of middle-class respectability in India portray stay-at-home mothers as respectable women (Radhakrishnan 2009, 2011). In the IT sector, Indian women often "choose" family over career and either leave their jobs after childbirth, reduce their workload or decline opportunities for promotion (2011:156). In many cases this is a wholehearted decision; the few who show ambivalence are considered less respectable (2011:154). Additionally, Indian women going out alone or interacting with men after working hours-a necessity when building a professional career (Phadke 2007) -lose respectability and moral propriety (Patel 2006). Despite women's cultural and economic capitals of high educational and professional achievements in Sri Lanka, visible changes in women's roles as nurturers and caregivers cause loss of respectability (Fernando and Cohen 2013). Hence, professional aspiration is considered outside the boundaries of respectable femininity in South Asia.

Yet in contemporary Bangladesh and elsewhere in South Asia, middle-class women are expected to contribute to household income, and/or bring bridal wealth/dowry or inherited assets to reinforce the family's affluent class status, thus investing in the family through economic capitals (Sabur 2014). Although such shifts enable many women to have careers and enter the public realm, their families remain a dominant factor in their lives, and some families still expect women to stay at home. Some women conform to such expectations, while others defy them and even file for divorce (Sabur 2014; Parvez 2011; Karim 2012). The present research adds to this nascent body literature, which identifies instances of negotiating respectability in relation to women's domestic roles.

Binaries and boundaries of classed construction of respectability are central to this discussion. To theorize new or alternative forms of middle-class respectable femininity in Bangladesh, I use the concepts of negotiation and boundary work. Pereira (2010:27) draws from the Latin etymology of "negotiation": neg meaning "not," and otium, "leisure" or "rest," thus "no rest." Negotiation is continuous, endless, and demands boundary work. I find Pereira's understanding of boundary work as an everyday and ongoing labor useful for understanding how respectability is used by middle-class women to perform continuous boundary work in order to negotiate with binaries of respectable (domestic duties) and unrespectable practices (professional/personal aspiration). Lamont (1992:11) defines boundary work as personal investment in identity: "[boundaries] emerge when we try to define who we are: we constantly draw inferences concerning our similarities to, and differences from, others, indirectly producing typification systems." "Typification systems" indicate that boundary work guides and organizes both the self and other social identities into categories. For this research, Lamont's typifications can be read as Bourdieu's various capitals (economic, cultural, social and symbolic). However, Bourdieu's understanding of distinction assumes that people with similar tastes and capitals tend to stay together, contributing to the reproduction of class structure. But to Lamont some boundaries are weak, and individuals do not always draw boundaries corresponding to their collective identity and taste, but rather to societal factors, such as profession, age or income, which can also influence individual ways of drawing boundaries that are different from other members of their class $(1992: 115,147)$. Thus, through boundary work, women can create and recreate class distinctions and their new middle-class status. 
10 I seek to explore to what extent professional women can negotiate with the normative conceptions of Bengali middle-class respectable femininity, introduce alternative forms of respectable femininity, and contribute to the creation of a new affluent middle class in Dhaka, Bangladesh. I will do so by investigating whether the participants conform and negotiate with permeable and shifting boundaries of Bengali middle-class respectability within the family, legitimizing their professional careers and capital investments in the family as respectable practices as opposed to prioritizing family above all.

\section{The Bangladeshi context}

11 Bangladesh is one of the "Next Eleven Tier" of developing countries, with a high potential of becoming one of the world's largest economies in the twenty-first century (BBC 2014). Although women's formal waged employment remains fairly low, it has more than tripled from 5.4 million in 1996 to 17.2 million in 2010, while men's labor force increased from 30.6 million to 39.5 million (BBS 2012:63). Neo-liberalization gave poor Bangladeshi women access to the market: micro-finance ${ }^{5}$ for rural women and the ready-made garment industry for urban women. Studies of working women in Bangladesh primarily focus on poor women's participation in garment factories (the industry sector employs $13.32 \%$ of all working women) or micro-finance (the agricultural sector employs $68.84 \%$ of all working women), overlooking the service sector, which employs the second largest proportion (21.89\%) (BBS 2010:46).

Some research and news items identify a booming middle-class community in Bangladesh, who are affluent, engaged in the global consumer market and transnationally mobile (Sabur 2010; Karim 2012; Rashid 2012; Sadique 2013). Although $31.5 \%$ of Bangladesh's population still live below the poverty line (Government of People's Republic of Bangladesh 2014), in the past decade the middle class has nearly doubled to approximately 30 million, more than the populations of Sweden, Norway and Denmark combined and the incomes of the middle class have doubled as well, increasing Bangladesh's private consumption to nearly $£ 66$ billion every year (Sadique 2013). The income bracket of middle-class households is $£ 6,600-£ 9,900$, which is a combined income from salary, small or medium-sized businesses, earnings from land sales or real estate rents, or investment in the capital market (Rashid 2012). However, there is little research on the impact of neoliberal movements on this rising middle-class community's women. Thus, it is important to ask to what extent all women, rather than just rural and urban poor women, have benefited from globalization and neoliberalization in Bangladeshi society.

13 Finally, Bangladesh is identified as a patriarchal country. With no welfare state, professional women have no state-funded childcare. In fact, in Dhaka, the capital of Bangladesh, there are only a handful of private childcare facilities, which are extremely expensive. Some NGOs have their own day care centers, for their employees only. In addition, part-time family-friendly jobs are unheard of for women in mid- to upper-level professions. 


\section{Research design}

14 year (January-December 2013) with 21 participants, aged 32-45, in Dhaka. However, owing to the focus on conjugal families this paper will only use the data of 17 married participants. Two semi-structured interviews were conducted with all participants within this year: the first face to face, and the second via phone or Skype. Email questionnaires were used to collect some clarification data. Most participants spoke in a mixture of English and Bengali, a common form of speech among urban middle-class Bangladeshis and a defining characteristic of the new middle-class. This helped me overcome the difficulty of the accurate translation of Bengali words. In addition, I often asked for friends and family members' suggestions on translation. For example, participants constantly used the term man shonman, which literally means "measure of reputation." Following much discussion with friends and family, I decided to translate it as "respectability," which later became a key conceptual framework for my data analysis. The participants shared some common characteristics: they all lived in Dhaka city, were qualified to graduate level or above and were mid- to upper-level professionals. But there were also some differences: 11 were married with children, 6 married with no children. There were differences in household settings and they lived in different areas in Dhaka. All participants were selected using the snowball method: I identified a small group of people relevant to the research questions, who proposed other participants with the relevant experience and characteristics (Bryman 2012:424). To avoid any inherent bias in the method, I used several snowballs in this research. I sampled women from my peers, ex-colleagues, managers, friends, and family members and then expanded this to distant informants who self-identified as middle-class, who lived in Dhaka, had tertiary education, and were in mid- to upper-level positions in their careers. I started with four participants from my network, who then expanded my snowball to include the rest of the participants.

The lifecycle of participants' household settings had a significant impact on their familial negotiations. Following are the three household settings of the participants:

1. Nuclear household: Participants live with husband and children in a separate location from their extended family. Seven participants live in this household setting. They are in the middle to older age range and their extended families live outside Dhaka.

2. Semi-extended household: Extended families live like neighbors, yet function as a family. Participants live next door to their in-laws, in housing owned by their in-laws, mostly sharing resources such as food, household help and cars. Eight married participants live in such a household system. They are in the younger and middle age groups, are engaged in relatively low-paid jobs or have faced some financial difficulty.

3. Extended household: Different generations of married couples and their children share a single household and a common pool of resources. Only two participants live in this household setting and they are in the younger age group.

The following table shows participants' household settings: 
Table 1

\begin{tabular}{|c|c|c|c|c|c|}
\hline Number & Name & Age & Past Household and Area of City & $\begin{array}{l}\text { Present household and Area of } \\
\text { City }\end{array}$ & Boundary Keepers \\
\hline 1 & Nesa & 40 & Nuclear (Kolabagan) & Nuclear (Kolabagan) & In-laws live out of Dhaka \\
\hline 2 & Shumi & 39 & Nuclear (Banami) & Nuclear (Banami) & $\begin{array}{l}\text { In-laws live in separate } \\
\text { houssehold }\end{array}$ \\
\hline 3 & Farrah & 38 & Nuclear (Bashminthara) & Nuclear (Bashminhara) & In-laws live out of Dhaka \\
\hline 4 & Afrin & 35 & Nuclear (Univesiry housing-Nillkhet) & Nuclear (University Housing-Nillkhet) & In-laws live out of Dhaka \\
\hline 5 & Shamta & 35 & Extended (Banani) & Nuclear (Banami) & $\begin{array}{l}\text { In-laws live in separate } \\
\text { household }\end{array}$ \\
\hline 6 & Nadia & 45 & Extended (Mogbazar) & Nuclear (Uttara) & $\begin{array}{l}\text { In-laws live in separate } \\
\text { household }\end{array}$ \\
\hline 7 & Keya & 40 & Extended (Uttara) & Nuclear (Uttara) & $\begin{array}{l}\text { In-laws live in separate } \\
\text { household }\end{array}$ \\
\hline 8 & Faria & 34 & Extended (Panthopoth) & Semi-extended (Panthopoth) & In-laws live next door \\
\hline 9 & Tamanna & 34 & Extended (Panthopoth) & Semi-extended (Panthopoth) & In-laws live next door \\
\hline 10 & Sanjida & 35 & Extended (Bashimdhora) & Semi-extended (Bashminora) & In-laws live next door \\
\hline 11 & Rafia & 32 & Fxtended (Poribagh) & Semi-extended (Poribagh) & In-laws live next door \\
\hline 12 & Nafisa & 35 & Semi-extended (Kolabagan) & Semi-extended (Kolabagan) & In-laws live next door \\
\hline 13 & Fatema & 38 & Semi-extended (Niteton) & Semi-extended (Niketon) & In-laws live next door \\
\hline 14 & Nameen & 38 & Semi-extended (Eskaton) & Semi-extended (Eskaton) & In-laws live next door \\
\hline 15 & Sharia & 38 & Semi-extended (Gulshen) & Semi-extended (Gulshan) & In-laws live next door \\
\hline 16 & Maliha & 33 & Extended (Niketon) & Extended (Niketon) & Lives with in-laws \\
\hline 17 & Samia & 35 & Extended (Bashmincora) & Extended (Bashumihora) & Lives with in-laws \\
\hline
\end{tabular}

PARTICIPANTS' HOUSEHOLD LIFECYCLE

\section{Reinstating class distinction}

17 Participants in this research accrue and invest capitals in themselves and their families. In so doing they contribute to the construction of their class distinction, which gives them respectability within the family, enabling them to negotiate their domestic, caring, and socializing roles. Tamanna, who is the country manager of a multinational accounting firm and lives in a semi-extended household, explains:

I eat with my in-laws and live in one of my father-in-law's apartments right below them in the building. So our household expenses are only my household help's costs and my daughter's expenses. My husband is a saving man; I have learned to save from him. As we do not have to pay rent we both save considerably to be able to invest in something big, such as a car or land.

In semi-extended households most participants pay bills, the wage of household help and some food expenses (expenses are shared with their husbands) but there is no formal financial contribution to the extended family. However, there exist various informal ways of making financial contributions, such as gifts.

In the above quote Tamanna recognizes that because of the money she and her husband save on rent and food, they are able to make long-term economic investments. It is important to note that Tamanna's mother-n-law (MIL) and father-in-law disapproved of Tamanna going back to work after childbirth, a normative expectation of middle-class respectable femininity. Tamanna's MIL initially refused to provide any childcare support to her, but eventually relented. Tamanna explains:

I guess my MIL noticed how my husband is supportive of my career, and due to my income, we are now doing so much better economically as opposed to my brotherin-law and sister-in-law. My sister-in-law had to give up her wish to pursue a career as her husband and my parents-in-law did not want her to work after having children.. 

complete breakdown of the extended family setting is a loss of status, power and respectability for the older generation as well as a loss of access to a privileged lifestyle and support with childcare and chores for the younger generation. Owing to neoliberalization and women's increased participation in paid work, both generations look for the best of both worlds. The older generation may prefer to help the younger generation by providing a support system, both economically and in household chores and childcare, in the form of semi-extended households. And younger families like Tamanna's can negotiate a better work/home-life balance by utilizing the extended family's support system and enjoying the economic stability of an affluent middle-class lifestyle. The younger family's further investment in the family through the acquisition of long-term consumer goods or assets to increase class distinction is a symbol of their respectable position in the family, and may be a reason for the older generation's acceptance of such changing household settings.

Semi-extended households also appear to provide young married participants increased opportunity to spend on children's concerted development (Lareau 2011), an investment in children's cultural capital as well as a sign of class status. Faria, who runs her own clothing business, explains:

now that we have children, we need to spend on our sons to give them a good education in an English-medium school, take them to different classes for extracurricular activities etc. For all this we bought a car, although before we could just use my in-laws' car.

A semi-extended household setting gives Faria the economic flexibility and autonomy to reproduce class privilege through concerted cultivation (Lareau 2011), whereby middleclass parents cultivate talents in their children by organizing children's leisure activities, and stimulating children's cognitive and social development. Faria's ability to afford the cultural capital of concerted cultivation and English-medium schooling (considerably more expensive than Bengali-medium schooling) signifies and reproduces her middleclass privilege, thus her family's social status, and that of the next generation. Fifteen participants' children attend high-fee English-medium schools; only two participants' children attend low-fee schools, and they both live in nuclear families with no shared resources.

In semi-extended and extended households, the older generation does not lose face in the community or social network for the complete breakdown of the extended household and control over daughters-in-law (DIL), while the participants in this study can accrue more capital, which they reinvest in the family. Working women use this investment as a legitimate source of respectability and maintain work/home balance. This choice to use

South Asia Multidisciplinary Academic Journal, 16 | 2017 
shared resources to maintain a middle-class lifestyle and further accrue long-term economic and cultural capitals for their family and the next generation is a key form of boundary work, whereby women are negotiating the boundaries of respectable household settings and intergenerational relationships.

\section{Substituting domestic work}

Some married participants in semi-extended and extended households are able to convert kin relations within their in-laws' family, making allies who take over participants' childcare responsibilities. Participants with younger children are particularly keen on securing the allegiance of their MILs, so they can pursue their careers after marriage and motherhood. I construct MILs as boundary keepers, individuals who police women's performance of respectable femininity and help or hinder women's boundary work in relation to negotiating boundaries of respectability and work-life balance. As discussed in the first section, through playing a symbolic role in relation to reproducing class privilege, women build a protective shield, enabling them to find substitutes for their gendered domestic work, such as food preparation, childcare etc., and avoid the disciplining of their families. Faria explains:

When I was in my first job with an international NGO, where I had regular field work in the villages, I could not give enough time to do household work like my homemaker sister-in-law, and that worried me. So to please my in-laws, especially my MIL, I used to try to cook even after returning from field work, completely exhausted! I am a very bad cook! I used to call my mother to ask what I should put next in a recipe... I kept thinking God knows what my MIL is thinking of me, that this girl does not know anything about a household! ... Now (after moving to semiextended household) I only help out in cooking during social gatherings.

Faria's comment illuminates two things: first, that the normative conception of middleclass respectability requires daughters-in-law to participate in household chores; second, that professional women are often unable to meet such requirements to the same extent as homemakers, and thus look to negotiate by finding substitutes for this work. But this negotiation is only acceptable if they maintain a public display of doing domestic chores, like cooking during social gatherings. Most participants in semi-extended and extended household settings (15 participants) eat with their in-laws or have food sent to them and do not participate in everyday food preparation, which is acceptable, as these negotiations of domestic work remain hidden from society. I read such shared arrangements and public displays of household chores as a negotiation of normative conceptions of respectability. Boundary keepers such as MILs are more accepting of this, as they can still maintain a public display of control over DILs' time and unpaid labor within the home as DILs participate in household chores during parties in front of others.

Notably, none of the participants living in semi-extended and extended households participate in everyday domestic duties such as food preparation, and they all share their childcare responsibilities with their MILs and household help. MILs also depend on household help for everyday chores. All participants who have children and live in semiextended households, like Fatema, Faria, Tamanna, Nafisa and Shazia, (Rafia was pregnant at the time of interviews so it is unknown what arrangement she would have once she had the baby), have their own household helpers who primarily assist with childcare, but may also contribute to cleaning and food preparation. However, all household helpers are supervised by the MILs. 

Samia depends heavily on her MIL for childcare (discussed in the next section) not only while she is at work but also when she goes on holidays with her husband, leaving her children with her MIL.

Fon a securing the allegiance of boundary keepers of respectability within the family, such as the MIL:

I had both my children while I was studying. I started working right after graduation and depended on my MIL to take care of the children. After my husband went bankrupt in his business I switched to this job, which is much more demanding in terms of hours and foreign travel than my previous job. I still depend on my MIL, who lives next door to us, for everyday childcare. When I go on foreign travel, I sometimes leave my children with my parents, to give my MIL a break.

Fatema acknowledges her dependence on her MIL for childcare, and gives her MIL breaks when she goes away to foreign countries. This shows a reversal of control over women's time and unpaid labor, whereby contrary to the normative command of the MIL over the DIL's time and labor, in Fatema's case the DIL is also able to obtain control over the MIL's unpaid labor. I identify this role reversal as an example of Fatema's boundary work, simultaneously negotiating norms of respectability by co-opting her MIL to take care of children for her and changing generational power relations. The role reversal can be further observed in participants' comments about how, although they cannot pay their MIL for childcare, they try to compensate in other ways, investing in their MILs' social status.

Faria says:

In the morning I bathe my sons, feed them and prepare their whole day's schedule and leave my in-laws in charge. I recognize what a big favor my in-laws are doing for me. I often give them expensive gifts, or take them on holidays to show our gratitude.

Faria takes on a considerable amount of labor to access the support of the boundary keepers. Thus the participants in this study are efficient managers of household labor, though they also depend on boundary keepers for support. In addition, Faria compensates for the shared childcare of her MIL through expensive gifts and holidays. I identify participants' purchase of expensive gifts and holidays for their MIL as a classed strategy, which simultaneously obliges the MIL to return the favor through childcare, and also maintains the boundary keeper's class status (through the cultural capital of a holiday). In turn participants save money on professional childcare (as mentioned above, day care is limited in Dhaka and extremely expensive), and more importantly gain the loyalty of the MIL. The MIL's loyalty reduces women's childcare responsibilities as well as the chances of being disciplined for the avoidance of domestic work, enabling them to give their career as much importance as family. Such familial support is not available to participants in nuclear household settings like Nesa, Shumi, Nadia, Keya, Farrah, Afrin and Shanta, who are indeed stretching the boundaries of normative respectability, but at the price of the double burden of supervising household help for childcare and domestic chores as well as maintaining their careers.

The dominant literature on the MIL-DIL relationship argues that in South Asian MILs have power over DILs (Vera-Sanso 1999; Jejeebhoy and Sathar 2001; Naved and Persson 2005; Chowdhury 2010; Rozario and Samuel 2012; Schuler et al. 2013). The duty of the DIL, who was traditionally called a jhi (maidservant) in Bengali, is to nurture the family through cooking, childrearing, and serving the male members of the family, 
working closely with her MIL (Donner 2008:79). But De Neve (2011:91) notes that kinship bonds such as MIL-DIL can also facilitate middle-class women's access to employment thanks to the availability of childcare in countries like India. He further argues that urbanization enhances such use of wider family networks for young working women. My findings support this and expand upon it by arguing that women's active participation in paid employment is shifting the power relation between women and their kin, in this case the MIL. But participants also compensate for their MILs' support for their career through childcare and by trading domestic work for gifts and holidays. Sabur (2010) has argued that tourism and gift giving and receiving are an important form of social exchange and are meticulously maintained by the Bangladeshi affluent middle class. Privileged class consumption patterns through foreign travel and gifts represent their discerning taste and are explicitly displayed, distinguishing them from other classes. Thus, participants' appreciation of boundary keepers' services through gifts adds value to their MILs' class status, and enables women to maintain the symbolic respectability of adding value to their families and to negotiate older boundaries of respectable femininity in relation to domestic and caring roles.

\section{Concealing unrespectable practices}

Some participants living in semi-extended and nuclear households are also able to conceal practices that are considered unrespectable or outside the boundaries of moral propriety and escape the scrutiny of their in-laws, such as staying out at night/after office hours for work events. Nadia explains:

Before when I used to live with my in-laws the nature of my job required me to attend work dinners without my spouse. During busy times I often had to stay at work till midnight and sometimes after a successful project I just wanted to celebrate with my team and go out. This used to bother my mother-in-law... I would always have to call her personally to tell her that I was going to have dinner out and often had to tolerate angry glares and frowns when I returned home late.

In extended families participants have to maintain certain normative conceptions of moral respectability, including not being outside alone after working hours. Previously Nadia was expected to account for herself to her MIL if she was going to be out late, and endure the "discipline" of disapproval for transgressing moral boundaries of respectability. Sanjida adds that women working in the corporate sector are always perceived as losing respectability through night-time work events, and thus semiextended households are the most suitable setting for corporate professionals, to avoid families' disapproval of such professional practices while also utilizing family support for domestic chores and childcare.

When I was single I had no restrictions on attending work parties or hanging out with friends till late at night. But after my marriage, even though my husband and I were going to the same work events, these were not very well-accepted by my mother-in-law ... since we moved next door to her I am now able to go back to my old lifestyle.

All fifteen participants in semi-extended and nuclear households are able to negotiate with moral norms of respectable femininity (not applicable to men, as Sanjida's husband did not receive any disapproval) by partaking in night-time socializing for work once they have moved out of sight of their in-laws. The participants see socializing, both professional and social, as part of their class culture, a lifestyle, and through semi- 
extended (and nuclear) family settings, they are able to avoid the disapproving "discipline" of their kin/boundary keepers.

Again, it is women's capital investment in the family that enables their negotiation of the moral restraints of night time-socializing for work. Samia says:

My mother-in-law left her 25-year career as a professor of sociology to take care of me and my sister-in-law's (husband's brother's wife) children. You see, I work for my husband's company. It was established by my father-in-law; after he passed away my husband and brother in-law have taken over and as the eldest daughterin-law I joined the company right after our marriage. At the end of the day my professional success contributed to my in-laws' business, so they appreciate my involvement in this business. I also never get any pressure from my MIL to quit my job although as the director of public relations my working hours require me to stay out till late a couple of days a week ... it's a give-and-take relationship for me.

The fact that Samia considers her relationship with her in-laws as a "give-and-take" relationship is an example of the acceptability of mutual benefit from women's professional work, for both the woman and the boundary keeper, the MIL. While Samia's paid labor in her husband's firm adds economic value to the company, her MIL's unpaid labor at home facilitates capital investment by Samia in her family. Through contribution to the family business, some women are able to negotiate boundaries of respectability in relation to motherhood duties and night-time work.

Being seen alone at night without their husband is considered especially unacceptable for married women in South Asia (Fernando and Cohen 2013). But eating out, hanging out with friends in cafes (Sabur 2010; Janeja 2010) and attending Western-style parties (which include alcohol consumption and dancing) are considered part of the lifestyle of younger middle-class people in Bangladesh (Sabur 2010). For the previous generation "eating out" was an occasional affair, and only involved family members. Thus to participants' in-laws, night-time socializing without the rest of the family is an alien concept, and corporate parties an immoral space for women. Hence, there seems to be generational change in the conceptualization of the new and affluent middle-class lifestyle and women's respectability, which is being reconciled through semi-extended and nuclear households.

\section{Negotiating investment in familial social capital}

Participants also conform and negotiate with familial socializing duties such as attending and hosting social events. Social networks including kin and friendships are crucial for maintaining the class privilege and distinction of the middle-class lifestyle. Participants' comments illustrate that women are expected to sustain social networks and relationships for their families as part of their domestic duties and respectable femininity. All participants mentioned the requirement of being present at familial social events, such as festivals, weddings and family parties. Some of them conform to this, while others negotiate and manage such responsibilities more strategically, if they clash with work-related responsibilities.

Shumi holds a directorial position in a local NGO, has a young daughter and lives in a nuclear family where she has to take care of her daughter herself rather than relying on extended family. Shumi's multiple duties, along with her prestigious professional position, provide her with the respectability and negotiation power to ignore comments of extended family about her inability to maintain her socializing role. She says: 
I often arrive late for family parties due to work or miss out others. My MIL does not complain and when I am late she always comes to me and asks if I have eaten or should she take my daughter from me so I can relax and socialize. But many times other family members say things like-why do you need to work, it must be harming your daughter and you do not have time for the rest of your family either -I just smile and let things like this pass without getting distressed. I know they do this to make me feel guilty about working; by ignoring such comments I refuse to give in to their tactic.

Thirty-nine-year-old Shumi's extended family members construct women's work as a practice that harms their children and restricts them from giving time to their extended family and is thus outside the boundary of respectable femininity. But shumi's ambivalence towards such accusations is a form of negotiation of these normative conceptions of respectability in relation to performing socializing duties with the family. Although Shumi arrives late to parties, she does not avoid them altogether. Thus she is well aware of her responsibilities to socialize with her in-laws' family, and tries to participate in social events, even if she is late and has to endure rebukes.

Keya is forty, a manager of a manufacturing company, and shares a similar experience of extended family disapproval:

Every time I miss a family function my husband's family tries to give me a guilt trip! Some of them even call me the next day to say it was rude of me to give an excuse of work and not attend the function as the only DIL of the family. I have just learned to live with such accusations now.

Like Shumi's observations, Keya's statement illuminates that participants are not passive receptors of family expectations in relation to their socializing responsibilities; rather they actively interpret which aspects of these expectations to conform with and which to negotiate; thus do they do boundary work. They are also aware that, depending on their conformation and transgression, they will be rewarded or penalized through public criticism. Older participants hold higher positions in their careers and possibly also earn substantially, which adds value to their status in the family. Their professional position and accrued capital provide them with the scope to brush off rebukes when they choose to prioritize their careers over socializing with and for the family.

It is unclear in Keya's comment whether her husband attends those family functions that she is unable to attend due to work commitments. However, thirty-two-year old Rafia's comment demonstrates that rather than the son, it is the DIL's responsibility to attend:

My MIL always made it a point that I have to attend all weddings, birthdays, anniversaries or any other get-together in my in-laws' family. I also have to dress appropriately for these occasions... At the beginning of my marriage my MIL used to tell me which gold jewelry or which sari to wear. My husband rarely goes to these occasions, he has always been an introvert and never really enjoys going to big gatherings unless he knows the people very well. His family never forces him to attend these. But I was never given that option.

Sons are not necessarily required to attend social events or act as bearers of capitals. Rafia's person is a display of capitals for her in-laws' family, a consolidator of class and a primary site of forming distinction. This may be why the DIL's presence in social events is seen as more important than the son's, as femininity represented through embodiment practices of jewelry and clothing in social events represents the family's class status. This may be why the majority of the younger participants, Sanjida, Maliha and Afrin, who are either newly married, still at the lower end of their professional career, or in low-paid professions, often fulfill their socializing duties rather than negotiate. Particularly interesting is Afrin, who lives in a nuclear household in Dhaka but happily travels to 
Chittagong, a port city, to her in-laws' house for festivals and family get-togethers. The younger participants' fulfillment of their socializing duties for the family establishes that the normative conception of respectability in Bangladesh expects DILs to play an active role in social events, part of their familial function. Therefore, not performing these duties may result in penalties for transgressing the normative standards.

Men and women play different roles in maintaining social relations in Bangladesh. While men are in charge of entertaining friends and networks outside the home, women are in charge of maintaining both kin relationships and friendships at the familial level (Sabur 2010:208). Such practices construct middle-class married women's respectable roles within the marriage as crucial in terms of maintaining social capital. But such socializing norms make demands on women's time, making it difficult for them to achieve professional success. Younger participants seem to fulfill this requirement and retain the public performance of respectable femininity by socializing with the family. They also conform to the display of cultural and economic capital through the use of clothing and jewelry at social events. Older participants show ambivalence or just reject familial socializing duties. In the context of this research, I contend that these practices constitute the negotiation of middle-class women's respectability, measured in relation to women prioritizing familial duties above professional commitment. It is also worth noting that women often participate in entertaining friends and colleagues outside familial surroundings. I discussed this in the third section of this paper, Concealing unrespectable practices, where Nadia, Samia and Sanjida mentioned that they like to celebrate successful projects with colleagues and hang out with friends, which is identified as a man's role in socializing among the middle class. Thus I argue that participants are able to negotiate boundaries of respectability in relation to familial socializing duties and practice alternative forms of respectability through socializing roles that have been normatively associated with men.

\section{Conclusion}

This study aimed to contribute to literature on the changing realities of families in urban Bangladesh through alternative practices of the classed gender identity of respectable femininity. The normative conception of middle-class respectable femininity in South Asia is traditionally measured through women prioritizing family above work (Radhakrishnan 2009, 2011; Fernando and Cohen 2013; Sabur 2010). Even a woman who engages in the global economy of work and consumption must claim her high cultural and symbolic status through the "assertiveness and autonomy afforded by her education and earnings," which must still be focused on the service of the family and the nation (Gilbertson 2011:119; Radhakrishnan 2009; Mankekar 1999; Rajan 1993).

Based on the findings of the study I make three contributions. First, using Bourdieu's (2008) concepts of capitals and a feminist understanding of women's capital-accumulating strategies (Skeggs 1997), and Pereira (2010) and Lamont's (1992) formulation of boundary work as an everyday ongoing labor, I have demonstrated that the negotiation of normative conceptions of respectability is mediated by women's capital accumulation and legitimization strategies. The participants in this study maintain class privilege through investing capitals and legitimizing class taste for their conjugal family in relation to the economic capital of cars and land, the cultural capital of children's English-medium schools and concerted cultivation, and the social capital of attending family get- 
togethers, weddings and festivals. They also contribute to their in-laws' families by paying for household help and holidays, as well as giving gifts. Consumption and investment in long-term consumer goods and assets play a major role in self-definition and public representation and everyday practices of neoliberal middle-classness in South Asia (Donner and De Neve 2011). In Bangladesh, the family is the primary site for capital accumulation and maintenance, as individuals accumulate and preserve capitals for further investments to attain upward class mobility (Sabur 2010). I identify women's capital investment in the family as a significant resource which enables them to play a symbolic role in their family's class dominance, to obtain respectability and in turn substitute for their domestic, caring and socializing duties, and to participate in practices previously deemed unrespectable (even if in hiding).

Secondly, utilizing the investment of capitals in their families, some women negotiate domestic roles by co-opting MILs or household help, while others partake in night-time socializing (which is considered unrespectable) without the knowledge of the older family members. In relation to socializing duties, younger married women in the early stages of their career conform to such social capital maintenance responsibilities. However, older women in higher-level professional positions are able to show ambivalence towards pressure to perform these duties. Thus, women's age and career position also have an impact on their negotiations with boundaries of middle-class respectability in the family. This establishes that, rather than focusing on women's respectable or unrespectable practices, contemporary research needs to address women's ability to negotiate with the boundaries of respectable practices and legitimize alternative practices of respectable femininity.

41 Finally, women's negotiations are neither unitary nor homogeneous. Semi-extended households are more common among younger married participants with young children, and may be a step towards a nuclear home. There are variations on women co-opting their MILs for childcare, as some hire household help to support MILs in childcare, while others primarily depend on the MIL. Additionally, women of different ages and professional status approach socializing norms differently. I have also demonstrated that families respond differently to women's negotiations of respectability, according to inlaws' assets, MILs' willingness to provide childcare, etc. Often, women's wider extended families and society are more critical of their negotiations than their immediate families, who are thus not the ultimate arbitrators of women's respectable practices. However, I also argue that in this alternative form of negotiated respectability, older accountability structures remain unchanged, as women are still expected to carry out household chores, though they have found ways to navigate through these expectations and give their careers as much importance as their families; I identify this as an alternative form of respectable femininity.

To conclude, I have expanded the construction of the new affluent middle class in urban Bangladesh from propertied, highly-educated, English-speaking, internationally-mobile people engaged in the neoliberal market through business, civil society and multinational-company jobs (Mapril 2013) to include dual-income families where professional "new women," through their practices of alternative forms of respectable femininity, are contributing to their family's class status. "New women" have always been conceptualized as change agents. In Victorian Britain they represented political consciousness, professional identity and sexual freedom (Beetham and Heilmann 2004; Ledger 1997) and in colonial and post-colonial Bengal they represented nationalism 
against colonial rule in the public sphere and femininity and middle-class morality within the private sphere of the home (Chatterjee 1989). Such an understanding of "new women" is different from the studies of poor women's empowerment and autonomy in Bangladesh, which demonstrate that despite neoliberalism's integration of poor women in paid employment, their employment invokes hostility and anxiety about men and women's power relations within the family. Poor married women never spend money on themselves or their natal families and seek their marital family's affection and respect by carrying out all domestic chores, despite having jobs. They are highly dependent on their husbands and unwilling to disrupt marital relationships, despite child marriage, domestic violence, polygamy etc. (Kabeer 1997). I argue that alternative forms of respectable femininity, through giving both family and profession equal importance, are central to the construction and performance of "new womanhood" among affluent middle-class women in Bangladesh. Additionally, I propose that alternative forms of respectability are not exclusive to South Asia and can be further explored in studies of women's negotiation with familial duties all over the world, particularly in relation to how women negotiate their household duties through investment in their class status.

\section{BIBLIOGRAPHY}

Bangladesh Bureau of Statistics 2010. "Review of Labour Force Survey 2010.» Dhaka: BBS.

Bangladesh Bureau of Statistics 2012. “Gender Statistics of Bangladesh 2012.» Dhaka: BBS.

BBC. 2014. “Bangladesh Profile.” Retrieved October 21, 2014 (http://www.bbc.co.uk/news/worldsouth-asia-12650940).

Bates, Lisa M., Sidney R Schuler, Farzana Islam and Khairul M. Islam. 2004. "Socioeconomic Factors and Processes Associated with Domestic Violence in Rural Bangladesh." International Family Planning Perspectives 30(4):190-99.

Beetham, Margaret and Ann Heilmann. 2004. New Woman Hybridities: Femininity, Feminism and International Consumer Culture, 1880-1930. London: Routledge.

Bourdieu, Pierre. 1992. Distinction: A Social Critique of the Judgment of Taste. Translated by R. Nice. London: Routledge and Paul Kegan.

Bourdieu, Pierre. 2008. “The Forms of Capital.” Pp. 280-91 in Economic Sociology. USA, UK:

Blackwell Publishers Inc.

Bryman, Alan. 2012. Social Research Methods. Oxford and New York: Oxford University Press.

Chatterjee, Partha. 1989. "Colonialism, Nationalism and Colonialized Women: The Contest in India.” American Ethnologist 16(4):622-33.

Chowdhury, Farah D. 2009. “Theorising Patriarchy: The Bangladesh Context.” Asian Journal of Social Science 37(4):599-622.

Chowdhury, Farah D. 2010. “Middle-Class Married Women's Income in Bangladesh: Who Controls it and How?" African and Asian Studies 9(1):1-30. 
De Neve, Geert. 2011. “'Keeping It in the Family”: Work, Education and Gender Hierarchies among Tiruppr's Industrial Capitalists.” Pp. 73-99 in Being Middle-Class in India: A Way of Life edited by H. Donner. New York: Routledge.

Donner, Henrike and De Neve, Geert. 2011. "Introduction." Pp. 1-22 in Being Middle-Class in India: A Way of Life, edited by H. Donner. New York: Routledge.

Donner, Henrike. 2008. Domestic Goddesses: Maternity, Globalization and Middle-Class Identity in Contemporary India. Aldershot, Burlington, VT: Ashgate.

Fernando, Weerahannadige D. A. and Laurie Cohen. 2013. "Respectable Femininity and Career Agency: Exploring Paradoxical Imperatives.” Gender, Work \& Organization 21(2):141-69.

Frances, Raelene. 1994. “The History of Female Prostitution in Australia.” Pp. 27-56 in Sex Work and Sex Workers in Australia, edited by R. Perkins. Sydney: University of New South Wales Press. Government of People's Republic of Bangladesh. 2014. Millennium Development Goals: Bangladesh Country Report 2013. Retrieved October 21, 2014 (http://www.bd.undp.org/content/dam/ bangladesh/docs/Publications/Pub-2014/MDG\%20Report\%20Last.pdf)

Gilbertson, Amanda. 2011. Within the Limits: Respectability, Class and Gender in Hyderabad. PhD dissertation. University of Oxford.

Heath, Rachel. 2014. “Women's Access to Labor Market Opportunities, Control of Household Resources and Domestic Violence: Evidence from Bangladesh.” World Development 57:32-46.

Hussain, Nasrin A. 2010. "Religion and Modernity: Gender and Identity Politics in Bangladesh." Women's Studies International Forum 33:325-33.

Janeja, Manpreet. 2010. Transactions in Taste: The Collaborative Lives of Everyday Bengali Food. London: Routledge.

Jejeebhoy, Shireen J. and Zeba A Sathar. 2001 "Women's Autonomy in India and Pakistan: The influence of Religion and Region.” Population and Development Review 27(4):687-712.

Kabeer, Naila. 1991. "The Quest for National Identity: Women, Islam and the State in Bangladesh.” Feminist Review 37(1):38-58.

Kabeer, Naila. 1997. "Women, Wages and Intra-household Power Relations in Urban Bangladesh." Development and Change 28(2):261-302.

Kabeer, Naila. 2000. The Power to Choose: Bangladeshi Women and Labor Market Decisions in London and Dhaka. London and New York: Verso.

Karim, Shuchi. 2010. “Living Sexualities and Not Talking 'Straight': Understanding NonHeterosexual Women's Sexuality in Urban Middle-class Bangladesh.” OIDA International Journal of Sustainable Development 1(6):67-78.

Karim, Shuchi. 2012. Living Sexualities: Negotiating Heteronormativity in Middle-Class Bangladesh. PhD dissertation, International Institute of Social Studies, Erasmus University.

Koenig, Michael A., Saifuddin Ahmed, Miyan B Hossain and Khorshed A. Mozumder. 2003.

"Women's Status and Domestic Violence in Rural Bangladesh: Individual- and Community-level Effects." Demography 40(2):269-88.

Laberge, Suzanne. 1995. “Toward an Integration of Gender into Bourdieu's Concept of Cultural Capital." Sociology of Sport Journal 12:132-46.

Lamont, Michele. 1992. Money, Morals, and Manners: The Culture of the French and the American UpperMiddle Class. Chicago: University of Chicago Press. 
Lareau, Annette. 2011. Unequal Childhoods: Class, Race, and Family Life. Berkeley: University of California Press.

Ledger, Sally. 1997. The New Woman: Fiction and Feminism at the Fin de Siècle. Manchester: Manchester University Press.

Lewis, David. 2011. Bangladesh: Politics, Economy and Civil Society. Cambridge: Cambridge University Press.

Liechty, Mark. 2003. Suitably Modern: Making Middle-Class Culture in a New Consumer Society. Princeton: Princeton University Press.

Lovell, Terri. 2000. “Thinking Feminism with and against Bourdieu." Feminist Theory 1(1):11-32.

Mapril, Jose. 2013. "The Dreams of Middle Class: Consumption, Life-Course and Migration between Bangladesh and Portugal.” Modern Asian Studies 48(3):693-719.

Mankekar, Purnima. 1999. Screening Culture, Viewing Politics: An Ethnography of Television, Womanhood, and Nation in Postcolonial India. Durham: Duke University Press.

McDowell, Linda. 2008. "Thinking through Class and Gender in the Context of Working-Class Studies." Antipode 40:20-24.

Menon, Nivedita. 2005. "Between the Burqa and the Beauty Parlour? Globalization, Cultural Nationalism and Feminist Politics." Pp. 134-43 in Postcolonial Studies and Beyond. Raleigh, NC: Duke University Press.

Naher, Ainoon. 2010. "Defending Islam and Women's Honour against NGOs in Bangladesh." Women's Studies International Forum 33:316-24.

Naved, Rucira T. and Lars Å. Persson. 2005 "Factors Associated with Spousal Physical Violence against Women in Bangladesh." Studies in Family Planning 36(4):289-300.

Osella, Caroline and Filippo Osella. 2004. "Malayali Young Men and their Movie Heroes." Pp. 171201 in Masculinities in South Asia, by C. Osella and F. Osella. Delhi: Kali for Women.

Parvez, Kazi N. 2011. Social Changes and Women-Initiated Divorce in Dhaka, Bangladesh: Gaining or Losing Power? M.Phil., The University of Bergen.

Patel, Reena. 2006. "Working the Night Shift: Gender and the Global Economy." ACME: An International E-Journal for Critical Geographies 5(1):9-27.

Pereira, Maria D.M. 2010. Pushing the Boundaries of Knowledge: An Ethnography of Negotiations of the Epistemic Status of Women's, Gender, Feminist Studies in Portugal. PhD dissertation, London School of Economics.

Phadke, Shilpa. 2007. "Dangerous Liaisons, Women and Men: Risk and Reputation in Mumbai." Economic and Political Weekly 42(17):1510-81.

Radhakrishnan, Smitha. 2009. "Professional Women, Good Families: Respectable Femininity and the Cultural Politics of a 'New' India." Qualitative Sociology 32(2):195-212.

Radhakrishnan, Smitha. 2011. Appropriately Indian: Gender and Culture in a New Transnational Class. Durham and London: Duke University Press.

Rajan, Sunder R. 1993. Real and Imagined Women: Gender, Culture and Postcolonialism. London: Routledge.

Rashid, Mamun. 2012. Rising Middle-Class in Bangladesh. Financial Express. Retrieved January 28, 2015 (http://www.thefinancialexpress-bd.com/old/more.php?news_id=139310\& date=2012-08-07 ) 
Rozario, Santi. 2006. "The New Burqa in Bangladesh: Empowerment or Violation of Women's Rights?" Women's Studies International Forum 29:368-80.

Rozario, Santi and Geoffrey Samuel. 2012. "Young Muslim Women and the Islamic Family: Reflections on Conflicting Ideals in British Bangladeshi Life." Pp. 25-42 in Women in Islam. Netherlands: Springer.

Sabur, Seuty. 2014. "Marital Mobility in the Bangladeshi Middle Class: Matchmaking Strategies and Transnational Networks." South Asia: Journal of South Asian Studies 37(4):586-604.

Sabur, Seuty. 2010. Mobility Through Affinal Relations: Bangladeshi 'Middle-class,' Transnational Immigrants and Networking. PhD dissertation, National University of Singapore.

Sadique, Mahfuz. 2013 “Uniqlo Looks to Cash in on Bangladesh's Middle-Class." BBC News. Retrieved January 28, 2015 (http://www.bbc.co.uk/news/business-23222484)

Schuler, Sidney R., Sayed M. Hashemi, Ann P. Riley and Shireen Akhter. 1996. "Credit Programs, Patriarchy and Men's Violence against Women in Rural Bangladesh." Social Science \& Medicine 43 (12):1729-42.

Schuler, Sidney R., Sayed M. Hashemi, Ann P. Riley. 1997. “The Influence of Women's Changing Roles and Status in Bangladesh's Fertility Transition: Evidence from a Study of Credit Programs and Contraceptive Use." World Development 25(4):563-75.

Schuler, Sidney R., Rachel Lenzi, Sohela Nazneen and Lisa M. Bates. 2013. "Perceived Decline in Intimate Partner Violence against Women in Bangladesh: Qualitative Evidence." Studies in Family Planning 44(3):243-57.

Shahidullah, Muhammad. 1985. “Class Formation and Class Relations in Bangladesh.” Pp. 137-64 in Middle Classes in Dependent Countries, edited by D.L. Johnson. London: Sage Publications.

Skeggs, Beverley. 2004. Class, Self and Culture. London: Routledge.

Skeggs, Beverley. 1997. Formations of Class \& Gender: Becoming Respectable. London: Sage.

Van Schendel, Willem. 2009. A History of Bangladesh. Cambridge: Cambridge University Press.

Vera-Sanso, Penny. 1999. “Dominant Daughters-in-Law and Submissive Mothers-in-Law? Cooperation and Conflict in South India." Journal of the Royal Anthropological Institute 5(4):577-93.

Watt, Paul. 2008. "The Only Class in Town? Gentrification and the Middle-Class Colonization of the City and the Urban Imagination." International Journal of Urban and Regional Research 32:206-11.

Weber, Max. 1978. Economy and Society: An Outline of Interpretive Sociology. Berkeley: University of California Press.

White, Sarah C. 2010. "Domains of Contestation: Women's Empowerment and Islam in Bangladesh.” Women's Studies International Forum 33:334-44.

\section{NOTES}

1. An enveloping outer garment worn by women in some Islamic traditions. Often black in colour, it covers a woman's whole body and has a separate headscarf.

2. To Weber (1978:509), status, defined by lifestyle, may coincide with class, but they are otherwise in "sharp opposition." Wealth creates difference; it allows those who have it to claim the products of wealth (education, travel, cars, houses, etc.) as status products or marks of exclusive respectability. This conversion is a diagnostic characteristic of middle-class culture. 
3. Here I define the bhondromohila and bhodrolok (respectable man) culture following Donner, as "a cultural category ... [which] lost much of its influence in the countryside, and the newly emerging educated middle class" (2008:56-57). They embodied development of a distinctly urban lifestyle.

4. A spot on the forehead, between the eyebrows, "traditionally worn by Hindu women as a symbol of their marital status, but later adopted by Muslim and Hindu women as a cosmetic feature" (Kabeer 1991:56).

5. Microfinance is a group-based loan for entrepreneurs and small businesses lacking access to banking and related services. It was pioneered in Bangladesh by Nobel-Peace-prize-winner Mohammad Yunus in 1983, primarily targeting poor rural women.

\section{ABSTRACTS}

Using qualitative data, this article explains how affluent urban and new middle-class women in Bangladesh reconstruct the notion of respectable femininity within the family. The normative conception of middle-class women's respectability is measured against women prioritizing family above work by performing their domestic, care, and socializing roles and by maintaining moral propriety. Using Bourdieu's theory of capitals and Lamont's formulation of boundary work, I demonstrate that by reinstating class dominance, concealing unrespectable practices, evading their domestic work by co-opting others to do it, and maintaining a public display of socializing duties for the family, women can negotiate the boundaries of respectable femininity in Bangladesh. In so doing, women legitimize alternative forms of respectability in the family, which vary according to their age, profession and household setting. The paper shifts the focus of respectability research in South Asia from a binary construction of respectable and unrespectable practices to how women make and remake their respectable status and class privilege in neoliberal Bangladesh, and reflects on the implications for gender and class relations.

INDEX

Keywords: women, respectability, family, middle-class, Bangladesh, Bourdieu

\section{AUTHOR}

\section{NAZIA HUSSEIN}

Department of Sociology, London School of Economics and Political Science 